\title{
SYSTEMATIC ASSESSMENT OF THE INNOVATIVE POTENTIAL OF A RESEARCH UNIVERSITY*
}

\author{
Oksana Zhylinska ${ }^{1}$, Maksym Sitnicki ${ }^{2}$, Alona Vikulova ${ }^{3}$
}

\begin{abstract}
The purpose of the paper. This paper outlines a comprehensive study of the essence and the essential synthesis elements of a Research University's innovation capacity. The following tasks were set as the article's objectives: 1 ) to analyse the development of scientific thought in the field of innovation potential; 2 ) to provide the author's definition of the innovative potential of such a university; 3 ) to structure the system of evaluation of the university's innovation potential. This study examines the new realities of needs for universities of the 21 st Century to improve their development management through a focus on the concept of "open" innovations. Methodology. This research is based on a careful analysis of the innovation capacity by the evolution of scientific thought. Scientific literature has expressed varying and opposing views as to the nature of the innovation capacity. However, very little has been identified to empirically judge the university's innovation capacity. Results. The present work suggested definitions of "Research University's innovation capacity"through the main component based on a novel integration approach. That approach includes the unity of the three types of economic activity. Those three are the provision of educational services, the provision of high-tech business services (carrying out R\&D on a commercial basis), and innovative activities through commercialization of intellectual property. That also encompasses the creation of start-ups or spin-off companies, producing high technology products. The paper provides an opportunity to focus on a systemic approach to assessing the university. Proposed systematic evaluation of the university's innovation potential through its internal and external components: organizational and managerial component; information and methodical component; the intellectual component; the research component; production and technological component; financial component; marketing component; global networks; research laboratories of TNCs; scientific unions and organizations; international consortia. This approach to the assessment provides with a more extensive comprehension of the main fields of activities of the Research University. The interaction of these components gives an opportunity to obtain a synergistic effect that will lead to their mutual reinforcement in the strategic perspective. Practical implications. It can be used by experts to comprehensively assess the potential of a world-class university by training human resources, solving complicated scientific and technological issues in order to obtain the economic outputs. Value. This research highlights the necessity to review the approaches to assessment of the innovative potential in the Research University. The authors presented their own vision of the internal and external components of the innovative potential of the Research University.
\end{abstract}

Key words: research university, innovative potential of research university, components of innovation potential of research university, evaluation mechanism.

JEL Classification: 123, D20, D40, 121, 125

\footnotetext{
Corresponding author:

${ }^{1}$ Taras Shevchenko National University of Kyiv, Ukraine.

E-mail: zhylinska@ukr.net

ORCID: http://orcid.org/0000-0001-8366-0474

${ }^{2}$ Taras Shevchenko National University of Kyiv, Ukraine.

E-mail: maksym.sitnicki@ukr.net

ORCID: http://orcid.org/0000-0002-0452-0404

${ }^{3}$ Taras Shevchenko National University of Kyiv, Ukraine.

E-mail: vikulova@knu.ua

ORCID: http://orcid.org/0000-0001-8506-0966
}

\footnotetext{
* This scientific paper published with support by the Visegrad Fund and in the framework of the research project of fundamental research of the Department of Management of Innovation and Investment Activities of Taras Shevchenko National University of Kyiv "Innovative mechanisms to enhance the development of scientific and technological activities in Ukraine."
} 


\section{Introduction}

The requirement to research the scientific issues of formation and evaluation of the innovation potential of research universities was determined by the need to develop a new system of strategic management of their work. Needless to say, it has to be accomplished in the "open innovation" environment of the information society.

Accordingly, as of today, for the preparation of competitive managers, it is an important task to develop the innovative capacities of individuals who can be able to think creatively by generating non-standard solutions. It's intellectually alert person create the scientific elite of research universities and business corporations that change the world through the creation and implementation of innovations.

The actualization of this need is subsequent to the shift in the university's mission. This was the case in the era of the industrial economy with the dominant model of "closed innovation". Such universities were seen as an institution intended to generate public goods. That is, to develop new scientific and technical knowledge as the result of mainly fundamental research. Its mission was also seen to be the preparation of a new generation of researchers; future creators of new knowledge that realized their intellectual potential. This was to be done mostly outside the university and primarily in the research labs of public science or business sectors.

New realities and policies that encourage the activation of innovation between EU member states led to the adoption of the EU Commission's recommendations "Governance of Intellectual Property Rights and the Code of Practice for Universities and other public research organizations" (European Commission, 2008). This was done through the establishment of effective knowledge transfer channels and efficient management of intellectual property at the university level. Under this recommendation, the transfer of knowledge is defined as a strategic task. At the university level, it is implemented in large-scale measures to raise awareness and skills of students in the field of science and technology, intellectual property, knowledge transfer, and innovative entrepreneurship.

The newest realities of universities functioning in the twenty-first century make the need to improve the procedures objective for managing its development. This is all based on the concept of "open" innovations, using the tools of strategic management.

The purpose of this article is to conduct a comprehensive study on the essence of the innovative potential of a research university. It will generalize the elements that act as the object of evaluation in the system of strategic management of the universities' development. The following tasks were set as the article's objectives: 1) to analyse the development of scientific thought in the field of innovation potential;
2) to provide the author's definition of the innovative potential of such a university; 3 ) to structure the system of evaluation of the university's innovation potential.

\section{Materials and methods}

The main research question is a comprehensive study of the essence of the University's innovation potential and its components. This study then becomes one which forms the system and mechanism for this potential assessment. This requires a deductive approach, which is suitable for this type of conceptual study.

The dominant research methods are: the critical analysis and synthesis, the generalization method and the logical methods, and the method of structured comparison based on the literature review with the interpretative approach. The literature review was conducted based on primary sources. It was also done on queries into journal databases such as SCOPUS and the Web of Science. The WOS is the best-known reference indexing of international databases with sources capturing large lists of titles. A supplemented data source covers papers available on Google Scholar dealing with innovation potential and Research University as the keywords used in queries.

This research is based on a careful analysis of the development of scientific thought in the field of innovation potential. It provided the author's definition of the research potential of a university.

This study was carried out through the conceptual apparatus of investigation and formulated conclusions of logical generalization and abstraction. The results of the study were visualized through a graphical method. It takes into account the multidimensionality of the analysis, the theoretical and empirical unity principle.

\section{Literature review}

In the information society, as Harvard Business School professor Etzkowitz (2003) systematically disclosed in Open Innovations, universities as flagships of fundamental research should become partners of business structures (Chesbrough, 2003). In turn, this will stimulate innovation processes through efficient exchange of intellectual property.

The concept of the "triple spiral" described by Etzkowitz caused a wide resonance in the professional circles of researchers and practitioners of many countries of the world. The concept provided justification for understanding a university as a new centre and a driving force behind the socio-economic dynamics of states. In his work "Triple Spiral" (Etzkowitz, 2008), the author proposed the model of innovation development. This model states that in the XXI century, the development will mostly rely on the effective and close interaction of the following three subjects which are branches of the figurative spiral. Those three are all civic authorities, 
business, and universities. The updated latter has a central role to play owing to the growing importance of information and knowledge in their broadest sense. The synergistic effect, resulting from the interaction of these institutions, creates a driving force behind the emergence of new points contributing to national wealth. Some American researchers emphasized the need to attract research universities to implement the applied tasks of the regional economy (Florida, 2000).

The World Bank expert, Jamil Salmi, in his work "Creating World-class Universities" (Salmi, 2009; 2011), characterized research universities as facilities that play a crucial role in training professionals, top-level specialists, and researchers. It is assumed they would therefore be capable of generating new knowledge and creating national innovation systems. Among the three complementary factors underlying the creation of world-class universities, the effective management of the university based on a strategic vision and flexibility, plays one of the most important roles. The three factors are the high concentration of talent (teachers and students), availability of resources ensuring conditions for learning and conducting breakthrough research. At the same time, the strategic vision of university development from the standpoint of deploying the model of "open innovation" should be based on a systematic assessment of its potential.

In 2011, the scientific community summed up the results of the first century-long consideration of innovation issues. It was a tradition initiated by J. Schumpeter, a prominent economist of the twentieth century, after the publication of his fundamental work "Theory of Economic Development". It should be noted that the publication of this work in Ukrainian has become a landmark in Ukrainian economic thought (Shumpeter, 2011). Since then, this tradition continues and innovation potential becomes one of the objects of scientific research. It was later introduced as an economic category by K. Freeman and was used as a criterion to evaluate the source of system development based on innovations. It was mainly connected to the innovative potential of commercial structures with various activities aimed at maximizing profits in a competitive environment. In Ukrainian scientific thought, the problem of innovation potential was actualized first and foremost at the macroeconomic level by (Dobrov, 1989). A significant contribution to its development was made in the national report "Innovative Ukraine 2020" (Heyets, 2015). Foreign researchers also address the issue of innovation potential at the macro level. In this context, we highlight the works of (Sternberg, 2000), (Vedres, 2006), (Wixted, 2009) and (Nepelski, 2016). At the microeconomic level, the evaluation of innovation potential is the object of scientific research in the works of Ukrainian researchers (Chervanov, 2012), (Stadnyk, 2009), (Sitnicki, 2007), and others. It should be noted that modern scientific research of foreign researchers is mainly focused on the assessment of innovation potential at the level of an enterprise or organization. This is shown in particular by (Barney, 1990), (Dougherty, 1992), (Zizlavsky, 2011), (Saunila, 2012), etc. In some publications, the authors use the notion "innovative potential of the university," as, for example, in the work (Čorejová, Rostášová i Čorejová, 2017).

The qualitative training of managers is essential in the development of innovative potential in them. This is shown in modern scientific publications (Nowak and Sitnicki, 2018), the authors emphasize the important role of strategic flexibility and leadership of a research university. It is leadership in research universities that is a powerful stimulus for the development of the innovative potential of persons with an innovative type of thinking.

Such activities of research universities are aimed at the development of innovations and give them the opportunity to consolidate the status of World-Class Universities.

It is the strengthening of the innovative potential that research universities in the European Union are in urgent need of nowadays. Determining the priorities for the development of EU research universities based on the analysis of the world-class universities' ranking indicators is done in work (Sitnicki, 2018a). The author provided strategic recommendations for intensifying the innovative development of EU research universities.

The question of refining the rating indicators for the implementation of the strategic analysis and evaluation of the effectiveness of the research university has been studied in detail (Zhylinska and Sitnitskiy, 2018). The authors emphasize the important role of innovative potential in the consolidated rating of the research university.

The need for the development of innovative literacy in a digital university of the future and critical learning prospects are considered in fundamental work (Goodfellow and Lea, 2013). On the basis of this, a comprehensive model of digital research universities was developed (Sitnicki, 2018b). The author put forward the hypothesis that the research University of the Future will be based on the wide use of digital technologies and innovations. Such an approach will provide them with world leadership. Methodological aspects of the integrated development of research universities based on the world experience are shown in the scientific monograph (Sitnicki, 2018c).

At the same time, scientific literature lacks comprehensive research on the innovative potential of research universities.

Nowadays they have turned from the main subject of generating scientific and technical knowledge to the subject of its commercialization. To effectively implement the task of managing the development of a university, one should understand the components of its potential in order to have the possibility of performing an evaluation. 


\section{Results and extended opportunities for systematic assessment}

Analysing the essence of the definition of a university, it should be noted that in Ukrainian legislation, the term "research university" was defined (Resolution of the Cabinet of Ministers of Ukraine, 2010) as: a national higher educational institution that has significant scientific achievements, conducts research and innovation activities. It ensures integration of education and science into production, takes parts in the implementation of international projects and programs. The "research" status is given to an educational institution in order to enhance its importance as a centre of education and science that provides training of highly skilled scientific and pedagogical personnel. One that implements scientific achievements, technical and technological developments in practice, takes part in joint programs with other higher educational and scientific institutions joint programs. In the process, it prioritizes the directions of fundamental and applied scientific research to solve important socio-economic problems in various branches of econ. Therefore, in Ukraine, the status of a research university is an official status assigned to a certain number of higher education institutions that to be confirmed every seven years.

In the United States, the content of a research university is not characterized by it carrying out a normative, but a descriptive function. It is a function which serves as a mark of a university's compliance with certain educational, scientific and economic criteria. Those criteria are a high proportion of funds received by a university for fundamental and applied research, typically $50 \%$ or more of the general budget. Those funds are received exclusively on a competitive basis, not as privileges provided for special status recognition. It also has a diversity of disciplines being taught at the university. This will include a high proportion of doctoral recipients, as well as a significant number of teachers involved, including from abroad. It also supposes the availability of developed infrastructure. One with studies of both undergraduate and postgraduate students, as well as research and innovation infrastructure, including small and medium-sized enterprises operating in partnership with a relevant university to commercialize objects of industrial property. And finally it will have a high degree of academic and research autonomy, the existence of strong corporate ethics, which ensure a high level and continuity of scientific schools and substantial volumes of charitable donations from successful graduates (Ishchenko, 2012).

A contemporary discourse is with the consideration of research universities in the information society along with the deployment of an "open" innovations model which lies in the fact that they have transformed from being a sociocultural phenomenon into an economic phenomenon. At present, the revenues from licensing activities of leading research universities are compared with the income gained from the educational services they provide. A successful performance of these universities in the commercialization of scientific and technical knowledge generated by them can be compared with the research laboratories of some corporations. The difference lies in the fact that within the walls of these universities, the trainees acquire not only scientific and technical knowledge. They also receive thorough training that helps in generating economic information. This knowledge provides the opportunity to quickly commercializetheirownintellectual property through the patenting mechanism and license agreements. Another mechanism is the realization of intellectual property objects into innovative products. This is a practice implemented mainly by new companies, such as startups and spin-offs. As a rule, these companies founded by employees and graduates of universities commercialize and reify new knowledge using intellectual capital as the basis of their authorized capital. Such highly educated and proactive individuals have the greatest competitive advantages in labour markets creating new niches, as well as gaining the highest public ratings. Moreover, such practice offers greater opportunities as associations of such universities to allow students to enter professional circles of researchers and practitioners in the relevant discipline. This can be true even during their master's studies, as demonstrated by the successful experience of Ukrainian-Polish cooperation of polytechnic universities (Projekt polsko-ukraiński, 2015).

According to the conclusion of a research group that developed the Doctrine of Sustainable Development "Ukraine 2030", modern innovative development is based on the synergistic interaction between economy and culture. This has shortened the time frame between the formation of new ideas and their implementation. This related directly to the terms of the development of original artistic works, cultural products, innovative products and services based on scientific discoveries and technical inventions. In this respect, research universities play an important role of being centres that form clusters of a creative economy (Ukraine 2030: Doctrine of sustainable development, 2017).

The specificity of a university's research emphasizes its priority in such activities as searching for a scientific solution to the problems of humanity. This, in turn, leads to the implementation of innovative training programs for the scientific and pedagogical staff of universities, research institutions, and science-intensive industries. Commercial effects resulting from these activities are not seen as dominant. At the same time, the distribution of students in the areas of training at the universities should meet the needs of the innovative development of the national economy. This all takes into account a priority for scientific-natural sciences and engineering specialties. Therefore, we see the need to propose the author's interpretation of such an economic category as being the "innovative potential of a research university". 
Innovative potential of a research university is a set of available and ready for use internal and external resources and opportunities of a world-class university that enable it to effectively carry out its mission. This mission would automatically be in the spheres of education, research, and innovation. This activity would lead to solutions to socially significant problems by scientific means thus achieving socio-economic effects. Therefore, the innovation potential of such a university is a systemic concept that reflects the economic nature of its mission. This would be defined in the context of unity of three types of economic activity. Those three types are: 1) a provision of educational services; 2) a provision of knowledge-intensive business services (carrying out research and development on a commercial basis);3) developing innovation through the mechanisms of intellectual property commercialization or creation of a start-up or spin-off companies that produce science-intensive products.

Figure 1 shows the elements of a systematic assessment of the innovation potential of a research university. The peculiarity of the author's approach is that it proposes to assess the level of the innovation potential of each university, weighing not only on the totality of its internal elements (1-7) but also considering external elements of the environment (8-11). The latter significantly expand the capabilities of the assessment of a university in accordance with the concept of "open" innovation.

Further, we will characterize the influence and interaction of the components of the innovative potential of each qualified university.
1. Organizational and managerial component This builds an effective structure for the purpose of creation, implementation of innovations, and commercialization of scientific and technical knowledge. It also establishes links between the university's units for the implementation of its innovation strategy. It provides controls of the university's management system over its managed subsystem. There is a timely adaptation of personnel in the development and commercialization of innovations. It additionally offers efficient planning and distribution of financial resources. And, lastly, it determines an operative study of the market and the development of effective marketing strategies.

2. Information and methodical component - This includes the availability of the integrated automated system for managing university educational, scientific, and innovative activities. It likewise includes the availability of information on the developments in substantive areas of university research functionality. Within this is an information base for the operations of the management structure, along with methodical materials to improve personnel qualification. Importantly, there is a cost reduction in obtaining information, as well as an information base for marketing research.

3. The intellectual component - It is the presence of highly skilled personnel capable of developing and implementing new scientific developments, as well as managing them. It is equally the presence of an active mechanism for intellectual activity motivation and the association of an employee with his/her university

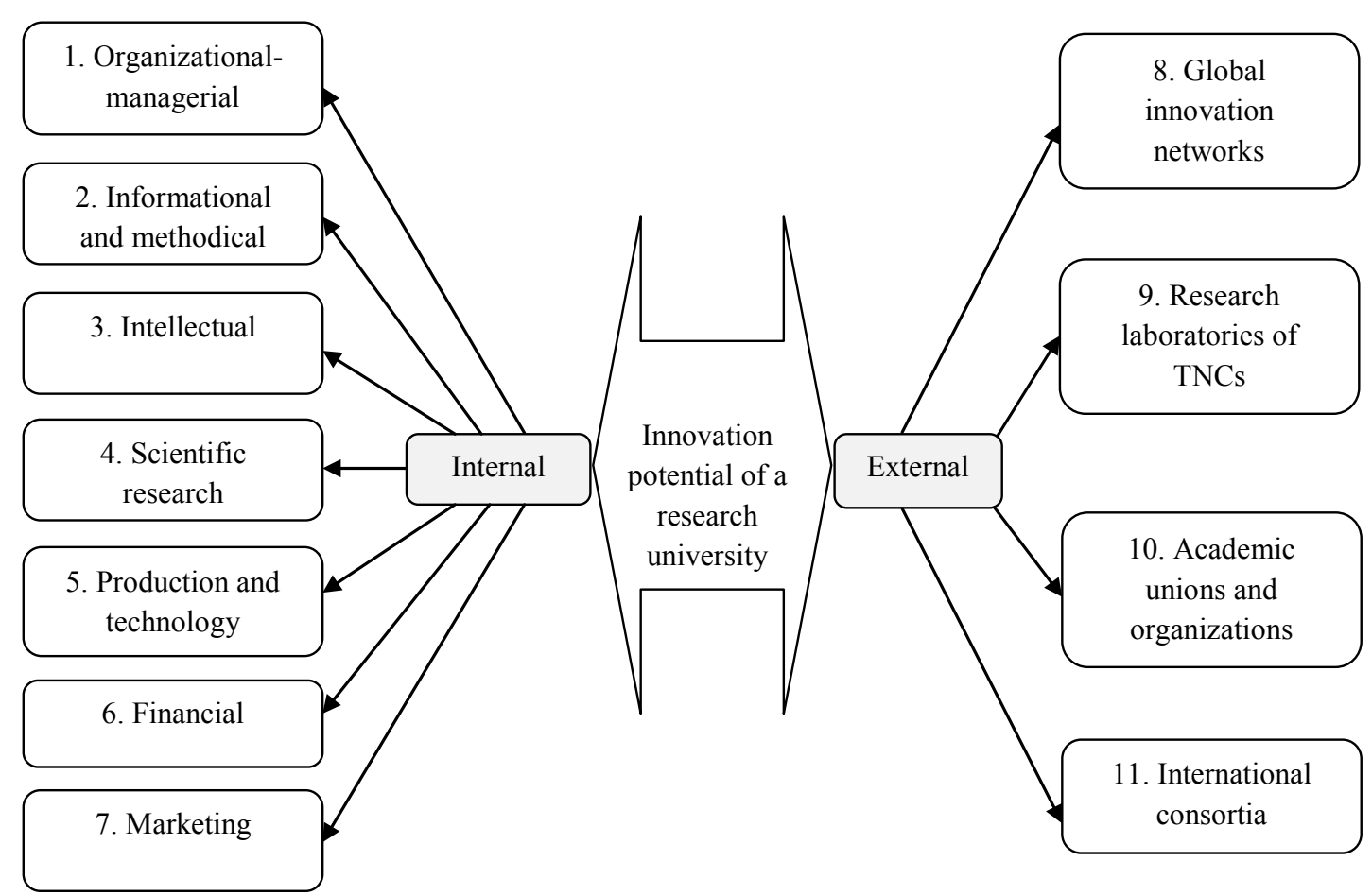

Figure 1. Systematic evaluation of the university's innovation potential through its internal and external components Source: developed by the authors 
and its research. This potential is also measured by the existence of quantitative and qualitative parameters within the management structure. It denotes cost reduction on training or attracting highly skilled personnel and provides the conditions to create knowledge-intensive (high-tech) products.

4. The research component - is a portfolio of patents, licenses, know-how, and other intellectual property objects. It also includes material and technical support necessary for research and development (R\&D) and the implementation of the educational process. All of this would be determined by the development of directions aimed to improve management structures, along with research of appropriate avenues of personnel development. It also means the provision of necessary technologies and thus high profits from the exclusive ownership status during a technological transfer. It, therefore, means the requirement of a competitive position in various markets: educational services, hightech (high-tech) products and other services.

5. Production and technological component - It includes the availability of production and technological support necessary for the production of high-tech products and services (technology, equipment, equipment, tools, etc.). The quantitative and qualitative characteristics of this potential have a significant impact on the competitiveness of a research university as a whole.

6. Financial component - A component which purports the availability of financial resources for the needs of effective innovation. It is realized through the financing of: 1) The costs needed for the formation and maintenance of innovation infrastructure. 2) The financing of the processes for the preparation and transfer of highly professional personnel. 3) Financing needed to improve the production of hightech products and services. 4) The creation of a stabilization fund; financing marketing research in new markets.

7. Marketing component - A key component that includes the availability of opportunities to apply effective marketing toolkit to implement and promote revolutionary new developments (high-tech marketing). This would be accomplished through: Research results, development and adjustment of strategies, and an effective marketing campaign.

8. Global networks - These are systemic organized groups that motivate their participants to innovate by achieving scientific results in jointly-defined long-term projects and areas.

9. Research laboratories of TNCs - This sets forth obtaining access to each of the universities' achievements regarding corporate structures in the process of specific order execution for a corporation. In this case, a university receives access to the data and technology of the corporate structure in order to objectively set the technical task and increase the efficiency of its implementation.

10. Scientific unions and organizations - These make it possible through a pooling of their efforts to solve the problems of industry. It allows them to have representation in the state authorities and international institutions in the area that deals with common problems faced by the university competitors for state financing increases. It helps to increase the growth rate of the scientifically intensive services market, which in turn leads to the emergence of new niches that increase the share of already existing innovative products.

11. International consortia - This provides for the availability of financial resources, equipment, unique specialists and technologies. It is realized through intergovernmental associations to solve global problems of mankind.

\section{Conclusions}

Thus summing up the results of the research, we can determine that the main principles that the evaluation system of the innovation potential of a research university should be based on include: 1) the responsibility of experts for the level of reasonableness of decisions in the strategic management of a research university development; 2) scientific and systematic assessment of the innovation potential of a research university; 3) complex orientation of the evaluation mechanism that includes internal and external components along with the effective implementation which will result in the formation of new competitive advantages in the globalized markets of educational services and knowledge-intensive business services.

The presented author's view on the system of innovation evaluation will enable experts to comprehensively assess the main reserves that the world-class university should reveal, addressing the scientific problems that it faces. It also looks at how they provide training for specialists who are capable of creating revolutionary scientific developments, embodying it in economic results. In general, the research university potential is largely determined by the effectiveness of the mechanism for the implementation of its components, which will be considered in further research.

\section{References:}

Barney, J., Baysinger, B. (1990). The organization of Schumpeterian innovation. Strategic Management in High Technology Firms, 19(2).

Chervanov, D. (2012). The system of innovative management: theory and practice. Kyiv University Publishing Center. 
Chesbrough, H. (2003). Open innovation: The new imperative for creating and profiting from technology. Boston, Mass: Harvard Business School Press.

Čorejová, A., Rostášová, M. \& Čorejová, T. (2017). Knowledge transfer model and spin-off company set up in significant academic centers in Taiwan. Procedia engineering, 192. doi: 10.1016/j.proeng.2017.06.015

Dobrov, G. (1989). Science about science. Kyiv: Naukova dumka.

Dougherty, D. (1992). Interpretive barriers to successful product innovation in large firms. Organization science, 3(2). Etzkowitz, H. (2008). The Triple Helix: University-Industry-Government Innovation in Action. London: Routledge. European Commission (2018). On the management of intellectual property in knowledge transfer activities and Code of Practice for universities and other public research organizations 2008/416/EC. Retrieved from: http://eur-lex.europa.eu/Lex UriServ.do?uri=OJ:L: 2008:146:0019:0024:EN:PDF (accessed 3 April 2018).

Florida, R. (2000). The Role of the University: Leveraging Talent, Not Technology. AAS Science and Technology Policy Yearbook 2000. A. Teich, S. Nelson, C. McEnaney, S. Lita (ed.) Wash. (DC): AAAS.

Goodfellow, R., Lea, M. R. (2013). Literacy in the digital university: critical perspectives on learning, scholarship, and technology. London; New York: Routledge Taylor \& Francis Group.

Heyets, V. (2015). Innovative Ukraine 2020: National Report. Edited by V. Heyets; National Academy of Sciences of Ukraine. Kyiv.

Ishchenko, A. (2012). Innovative research universities as a factor for the modernization of the educational-scientific sphere and the building of a knowledge society. Analytical note. National Institute for Strategic Studies. Retrieved from: http://www.niss.gov.ua/articles/1427 (accessed 3 April 2018).

Nepelski, D., Piroli, G. (2016). Organizational diversity and innovation potential of EU-funded research projects. The Journal of Technology Transfer. doi: 10.1007/s10961-017-9624-6

Nowak, A., Sitnicki, M. (2018). Strategic Flexibility of the Research University's Leadership. Interdisciplinary Journal of Economics and Business Law, 7 (3), 101-117.

Projekt polsko-ukraiński (2015). "Analiza wspótpracy uczelni polskich i ukraińskich na tle porównania systemów szkolnictwa wyższego. Wnioski i rekomendacje" we współdziałaniu m.in. z KRASP/KRPUT i RGNiSW - projekt własny FRP-ISW Prof. Jerzy Woźnicki, Konferencja Rektorów Akademickich Szkół Polskich, Poznań.

Resolution of the Cabinet of Ministers of Ukraine (2010). "On Approval of the Provision of a research university" of February 17, 2010 №163. Retrieved from: http://zakonl.rada.gov.ua/laws/show/163-2010\%D0\%BF? myid=4\%2FUMfPEGznhhm3c.ZiOXhkA6HdloQsFggkRbI1c (accessed 5 April 2018)

Salmi, J. (2009). The challenge of establishing world-class universities. Washington, DC: The World Bank.

Salmi, J. (2011). Nine Common Errors in Building a New World-Class University. International Higher Education, 62.

Saunila, M., Ukko, J. (2012). A conceptual framework for the measurement of innovation capability and its effects. Baltic Journal of Management, 7(4).

Shumpeter, J. (2011). The Theory of Economic Development: An Inquiry into Profits, Capital, Credit, Interest, and the Business Cycle. English trans. V. Stark. Kyiv: "Kyiv-Mohyla Academy" Publishing house.

Sitnicki, M. (2007). The influence of innovation potential on enterprose strategic flexibility. Ukrainian Statistics, 1. Sitnicki, M. (2018a). Determining the Priorities of the Development of EU Research Universities Based on the Analysis of Rating Indicators of World-Class Universities. Baltic Journal of European Studies Tallinn University of Technology, vol. 8, № 1(24), pp. 76-100. doi: 10.1515/bjes-2018-0006

Sitnicki, M. (2018b). Development of a Model of Digital Research Universities. Baltic Journal of Economic Studies, 4(1), 311-318. doi: 10.30525/2256-0742/2018-4-1-311-318

Sitnicki, M. W. (2018c). Strategic Management of the development of Research Universities: monograph. Kyiv: Publishing House Lira-K, 302 p.

Stadnyk, V. (2009). Systemne zabezpechennya motyvatsiyi innovatsiynoho rozvytku pidpryyemnytskykh struktur. KhNU.

Sternberg, R. (2000). Innovation networks and regional development-evidence from the European Regional Innovation Survey (ERIS): theoretical concepts, methodological approach, empirical basis and introduction to the theme issue. European Planning Studies, 8(4).

Zhylinska O., Melnychuk O., Antonyuk L. (2017). Ukraine 2030: Doctrine of sustainable development. Lviv: Kalvaria.

Vedres, A. (2006). Inventions and globalization: Innovation potential by countries. Budapest: International Federation of Inventors' Associations. Retrieved from: https://www.invention-ifia.ch/office/August/Innovation\%20 potential\%20by\%20countries.pdf (accessed 7 April 2018).

Wixted, B. (2009). Innovation System Frontiers: Cluster Networks and Global Value (Advances in Spatial Science). Berlin-Heidelberg: Springer. Retrieved from: http://dx.doi.org/10.1007/978-3-540-92786-0_5

Zhylinska O., Sitnitskiy M. (2018). Strategic Analysis and Evaluation of a Research University's Performance / In: Mărginean S., Ogrean C., Orăștean R. (eds) Emerging Issues in the Global Economy. Springer Proceedings in Business and Economics. Springer, Cham, pp. 407-417. doi: 10.1007/978-3-319-71876-7_36

Zizlavsky, O. (2011). Factors of an Innovation Potential Development are Known, but not Always Mastered. Economics and Management, 16. 